\title{
Informe
}

\section{Cultura empresarial en Caldas}

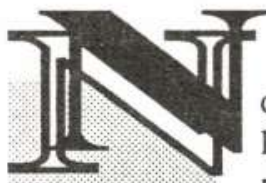

o es posible hablar del desarrollo industrial en Caldas sin mencionar el papel que el café ha jugado en el nacimiento de la industria manizaleña. Ella ántora nació del café, y ese rojo compañero de nacimiento aún lo cautiva y acompaña.

Pero no fue solo la trilla de café con su generación de amplio empleo la única circunstancia para el surgimiento de la industria fabril en Caldas. La crisis, de 1901-1905 hizo que muchos exportadores tuvieran que abandonar esta rama económica de la comercialización. Como consecuencia de ésta, una serie de capitales ociosos provenientes del cierre de bancos y compañías exportadoras buscaron nuevos rumbos de aplicación de dichas capitales, integrando la cultura alrededor de un sistema Agrícola-Industrial-Comercial y muchos de los valores y normas se subordinan a este sistema.

Todas las características de los hombres de negocios del Departamento de Caldas son el resultado de la interacción de variables culturales como las costumbres, la política, la religión, la familia y la educación.

«La cultura es esa compleja totalidad que incluye el conocimiento, el credo, el arte, la moral, el derecho, la costumbre y otros hábitos y cualidades cualesquiera adquiridas por el hombre como miembro de la sociedad. Por lo tanto, una cultura
Carlos Adriano Albarracín Arango Docente en facultades de Odontología y Fisioterapia de la Autónoma. Licenciado en Biología - Química y Administrador de Empresas

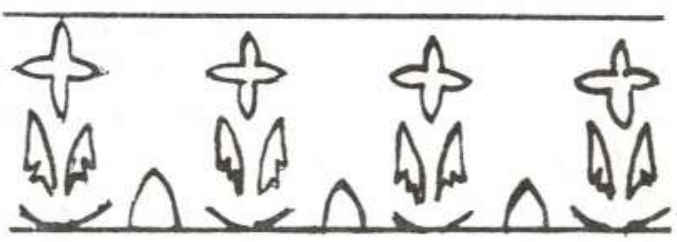

consiste en todas las pautas aprendidas de acción, sentimientos y pensamientos compartidos por los miembros de determinada sociedad. La cultura está compuesta por una serie de normas, que son las formas acostumbradas, convencionales y esperadas de actuar, pensar y sentir en esa sociedad. Así las normas incluyen los actos, las ideas, los valores, las reglas y las relaciones que la mayoría de las personas comparten en determinada sociedad. Las distintas partes de una cultura deben concordar armoniosamente para que el sistema funcione eficazmente. ${ }^{1}$

Se ubica al hombre de negocios como originario de los departamentos de Caldas y de Antioquia, lo

${ }^{1}$ Horton, P.B. Introducción a la Sociología, pág. 7 
que determina la similitud de muchas de las características entre los empresarios de las dos regiones.

En el actuar cotidiano de los empresarios se percibe un sentido racional para actuar. Su filiación política tiene una explicación lógica más allá de responder porque así era mi familia; los principios religiosos son cuidadosamente explicados de acuerdo a experiencias propias aunque en relación con la familia; conservan parámetros heredados de sus padres y socialmente aceptados en el medio en el cual se desenvuelven. Las profesiones de los empresarios caldenses se están diversificando, inclinándose en un alto porcentaje a las relacionadas con ciencias económicas, proporcionadas por las Universidades de la región, ofreciendo además post-grados específicos para campos del saber también muy concretos. La visión emprendedora y exploratoria a otros sectores diferentes a los agrícolas como son el industrial y el comercial, los cuales han alcanzado un grado de desarrollo, han dado lustre a algunos empresarios, y sobretodo han abierto posibilidades a otros; pero en ningún momento se han dejado de lado las labores del cultivo centradas en el café, al que se le debe en gran parte el progreso del Departamento.

Para clarificar el término racional, la psicología lo define como «conducta racional, la que se basa en un razonamiento correcto o lógicamente apropia- do a una situación»; y el razonamiento lo define como «el proceso del pensamiento que implica interferencia o resolución de problemas mediante el uso de principios generales"

Entonces al percibirse la transición de un empresario tradicionalista a racional se encuentran en éstos, atributos de personalidad que se consideran básicos como :
Innovación
De aspiraciones
Decidido
Sociable y
Ambicioso

Considerando la satisfacción de la gestión empresarial se definen estas características en orden de importancia:

\section{El éxito en los negocios}

2. Beneficio a la sociedad

3. Generación de empleo y

4. Crecimiento y desarrollo de la firma.

Bibliografía

HORTON, P.B. Introducción a la Sociología, Buenos Aires, Editorial el Ateneo 1973.

RODRIGUEZ BECERRA, Manuel. El Empresario Industrial del Viejo Caldas, Santafé de Bogotá, Universidad de los Andes 1979.



